\title{
The fruit juice of Morinda citrifolia (noni) downregulates HIF-1 $\alpha$ protein expression through inhibition of PKB, ERK-1/2, JNK-1 and S6 in manganese-stimulated A549 human lung cancer cells
}

\author{
BYEONG-CHURL JANG
}

Department of Medical Genetic Engineering, Keimyung University School of Medicine, Daegu 704-701, Republic of Korea

Received October 17, 2011; Accepted November 29, 2011

DOI: $10.3892 / \mathrm{ijmm} .2011 .860$

\begin{abstract}
High exposure of manganese is suggested to be a risk factor for many lung diseases. Evidence suggests anticancerous and antiangiogenic effects by products derived from Morinda citrifolia (noni) fruit. In this study, we investigated the effect of noni fruit juice (NFJ) on the expression of HIF-1 $\alpha$, a tumor angiogenic transcription factor in manganese-chloride (manganese)-stimulated A549 human lung carcinoma cells. Treatment with manganese largely induced expression of HIF-1 $\alpha$ protein but did not affect HIF-1 $\alpha$ mRNA expression in A549 cells, suggesting the metal-mediated co- and/or post-translational HIF-1 $\alpha$ upregulation. Manganese treatment also led to increased phosphorylation of extracellular-regulated protein kinase1/2 (ERK-1/2), c-Jun N-terminal kinase-1 (JNK-1), protein kinase $\mathrm{B}(\mathrm{PKB}), \mathrm{S} 6$ and eukaryotic translation initiation factor- $2 \alpha(\mathrm{eIF}-2 \alpha)$ in A549 cells. Of note, the exposure of NFJ inhibited the manganese-induced HIF-1 $\alpha$ protein upregulation in a concentration-dependent manner. Importantly, as assessed by results of pharmacological inhibition and siRNA transfection studies, the effect of NFJ on HIF-1 $\alpha$ protein downregulation seemed to be largely associated with the ability of NFJ to interfere with the metal's signaling to activate PKB, ERK-1/2, JNK-1 and S6 in A549 cells. It was further shown that NFJ could repress the induction of HIF-1 $\alpha$ protein by desferoxamine or interleukin-1 $\beta$ (IL-1 $\beta$ ), another HIF-1 $\alpha$ inducer in A549 cells. Thus, the present study provides the first evidence that NFJ has the ability to strongly downregulate manganese-induced HIF- $1 \alpha$ protein expression in A549 human lung cancer cells, which may suggest the
\end{abstract}

Correspondence to: Dr Byeong-Churl Jang, Department of Medical Genetic Engineering, Keimyung University School of Medicine, 2800 Dalgubeoldaero, Dalseo-Gu, Daegu 704-701, Republic of Korea E-mail: jangbc12@kmu.ac.kr

Key words: noni fruit juice, manganese, HIF-1 $\alpha$, protein kinase B, extracellular-regulated protein kinase-1/2, c-Jun N-terminal kinase-1, S6, A549 cells
NFJ-mediated beneficial effects on lung pathologies in which manganese and HIF-1 $\alpha$ overexpression play pathogenic roles.

\section{Introduction}

Morinda citrifolia (noni) has a long tradition as a medicinal plant in the Pacific islands and India $(1,2)$. Evidence suggests that products derived from the fruit of noni may have a wide range of potentially beneficial effects. For example, it is shown that noni fruit juice (NFJ) has anti-inflammatory and anticancerous activities $(3,4)$. There is further evidence to demonstrate that NFJ inhibits angiogenic initiation and disrupts newly established human vascular networks (5), indicating its antiangiogenic activity. However, the molecular and/or cellular mechanism underlying the NFJ-mediated antiangiogenic property remains unclear.

HIF-1 is a pro-angiogenic transcription factor composed of an $\alpha$ and a $\beta$ subunit (6). Characteristically, under normoxia and hypoxia, expression of HIF- $1 \alpha$ and HIF-1 $\beta$ are differentially regulated. While HIF- $1 \alpha$ protein is unstable and rapidly destructed via the proteasome- and E3 ubiquitin ligase von hippel lindau-mediated protein degradation pathway under normoxia, the protein is highly stabilized under hypoxia (7-10). The stabilized HIF-1 $\alpha$, under hypoxia, dimerizes with HIF-1 $\beta$ and this HIF- $1 \alpha / \beta$ dimeric complex involves in the transcriptional induction of hypoxia responsive elementcontaining genes involved in hypoxic adaptation and/or new blood vessel formation (11). However, the hypoxia-independent induction of HIF-1 $\alpha$ expression has also been reported. For example, it has previously been shown that interleukin- $1 \beta$ (IL-1 $\beta$ ), transforming growth factor- $\beta 1$ (TGF- $\beta 1$ ), insulin-like growth factor-1 (IGF-1) or certain heavy metals like manganese can induce the expression of HIF-1 $\alpha$ under normoxic conditions (12-17) and that the HIF- $1 \alpha$ inducibility by these factors is largely dependent of activities of multiple intracellular signaling proteins, including protein kinase $\mathrm{B}(\mathrm{PKB})$, extracellular-regulated protein kinase-1/2 (ERK-1/2), p38 mitogen-activated protein kinase (MAPK), c-Jun N-terminal kinase-1/2 (JNK-1/2), and/or nuclear factor- $\kappa \mathrm{B}(\mathrm{NF}-\kappa \mathrm{B})$ (14-18). Little is known about the relationship between NFJ and HIF-1 $\alpha$ expression.

In this study, we investigated the effect of NFJ on the expression of HIF-1 $\alpha$ in manganese-treated A549 human 
lung cancer cells and determined the possible molecular and cellular mechanisms involved.

\section{Materials and methods}

Materials. The fruit juice of Morinda citrifolia L. (noni) (NFJ) was purchased from Tahitian Gold Co., Inc. (Torrance, CA, USA) and stored at $4^{\circ} \mathrm{C}$ refrigerator until use. RPMI-1640 medium, fetal bovine serum (FBS), and penicillin-streptomycin were purchased from WelGENE (Daegu, Korea). Anti-rabbit polyclonal or mouse monoclonal antibodies were purchased from Santa Cruz Biotechnology, Inc. (Santa Cruz, CA, USA). Enzyme-linked chemiluminescence (ECL) Western detection reagents were purchased from Thermo Scientific (Waltham, MA, USA). Bradford reagent was bought from Bio-Rad (Hercules, CA, USA). The mouse monoclonal anti-human HIF-1 $\alpha$ antibody was obtained from BD Bioscience (San Jose, CA, USA). The antibody against HIF-1 $\beta$ was purchased from Santa Cruz Biotechnology, Inc. Antibodies against phosphoERK-1/2 (p-ERK-1/2), ERK-1/2, phospho-JNK-1/2 (p-JNK-1/2), JNK-1/2, phospho-PKB (p-PKB), PKB, phospho-S6 (p-S6), S6, or the $\alpha$ subunit of the eukaryotic translation initiation factor-2 (eIF-2 $\alpha$ ) were purchased from Cell Signaling Technology, Inc. (Danvers, MS, USA). The phospho-eIF-2 $\alpha$ (p-eIF-2 $\alpha$ ) antibody was acquired from Epitomics, Inc. (Burlingame, CA, USA). LY294002 and PD98059 were purchased from Biomol (Plymouth Meeting, PA, USA). SP600125, rapamycin and a proteinase inhibitor cocktail (100X) were purchased from Calbiochem (San Diego, CA, USA). IL-1 $\beta$ was purchased from R\&D Systems (Minneapolis, MN, USA). RT-PCR reagents were purchased from Promega (Madison, WI, USA). RNAzol-B reagent was purchased from Tel-Test (Houston, TX, USA). Plasticware of 6-well plates and 24-well plates was purchased from SPL Life Sciences (Gyeonggi-do, Korea). Other reagents, including manganese-chloride $\left(\mathrm{MnCl}_{2}\right)$, were purchased from Sigma (St. Louis, MO, USA).

Cell culture. A549 human lung carcinoma cells (CCL-185) were purchased from ATCC (Manassas, VA, USA). Cells were grown in RPMI supplemented with $10 \%$ heat-inactivated FBS, $100 \mathrm{U} / \mathrm{ml}$ penicillin, and $100 \mu \mathrm{g} / \mathrm{ml}$ streptomycin.

Preparation of whole cell lysates. To see the effect of manganese, IL-1 $\beta$ or desferoxamine in the absence or presence of NFJ on expression and phosphorylation (activity) of proteins, A549 cells $\left(0.5 \times 10^{6}\right.$ cells in $2 \mathrm{ml} /$ well in a 6 -well plate) were treated without or with these agents and/or inhibitors at the indicated concentrations or times. The conditioned cells were washed twice with phosphate-buffered saline supplemented with $1 \mathrm{mM} \mathrm{Na} \mathrm{VO}_{4}$ and $1 \mathrm{mM} \mathrm{NaF}$ and exposed to a modified RIPA cell lysis buffer [50 mM Tris-Cl (pH 7.4), $150 \mathrm{mM} \mathrm{NaCl}$, $0.1 \%$ sodium dodecyl sulfate (SDS), $0.25 \%$ sodium deoxycholate, $1 \%$ Triton X-100, 1\% Nonidet P-40, 1 mM EDTA, 1 mM EGTA and a proteinase inhibitor cocktail (1X)]. Cells were harvested and centrifuged for $20 \mathrm{~min}$ at $4^{\circ} \mathrm{C}$ at $12,000 \mathrm{rpm}$. The supernatant was saved and its protein concentration was determined with the Bradford reagent.

Total-RNA isolation and reverse transcription-polymerase chain reaction (RT-PCR). To determine the effect of manganese,
$\mathrm{IL}-1 \beta$ or desferoxamine in the absence or presence of NFJ on expression of HIF- $1 \alpha$ or actin mRNA, A549 cells $\left(0.5 \times 10^{6}\right.$ cells in $2 \mathrm{ml} /$ well in a 6-well plate) were treated without or with these agents in the indicated concentrations or times. Total cellular RNA was then isolated with RNAzol-B reagent according to the manufacture's protocol. Three micrograms of total-RNA were then reverse-transcribed using murine-molony leukemia virus (M-MLV) reverse transcriptase. Single stranded cDNA was amplified by PCR with the following primers: HIF-1 $\alpha$, sense, 5'-CTCAAAGTCGGACAGCCTCA-3'; antisense, 5'-CCCTGC AGTAGGTTTCTGCT-3'; actin sense, 5'-GTGCGCACACAT GCTTCTGT-3'; antisense, 5'-GGTAGGAACACGGAAGG CCA-3'. The PCR conditions applied were: HIF-1 $\alpha, 23$ cycles of denaturation at $95^{\circ} \mathrm{C}$ for $30 \mathrm{sec}$, annealing at $56^{\circ} \mathrm{C}$ for $30 \mathrm{sec}$, and extension at $72^{\circ} \mathrm{C}$ for $50 \mathrm{sec}$; actin, 30 cycles of denaturation at $95^{\circ} \mathrm{C}$ for $30 \mathrm{sec}$, annealing at $56^{\circ} \mathrm{C}$ for $30 \mathrm{sec}$, and extension at $72^{\circ} \mathrm{C}$ for $30 \mathrm{sec}$. The PCR products were run on $1.5 \%$ agarose gel electrophoresis at $100 \mathrm{~V}$ for $15 \mathrm{~min}$. Actin mRNA was used as an internal control to evaluate the relative expression of HIF- $1 \alpha$ mRNA.

Western blotting. An aliquot of whole cell lysate $(60 \mu \mathrm{g})$ was separated by SDS-PAGE (10\%). The separated proteins in the gel were then electrically transferred onto nitrocellulose membranes (Millipore, Billerica, MA, USA). The membranes were then washed with Tris-buffered saline (TBS, $10 \mathrm{mM}$ Tris, $150 \mathrm{mM} \mathrm{NaCl}$ ) supplemented with $0.05 \%$ (vol/vol) Tween-20 (TBST) followed by blocking with TBST containing 5\% (wt/ vol) non-fat dried milk. The membranes were incubated at $4^{\circ} \mathrm{C}$ overnight with antibodies specific for HIF-1 $\alpha(1: 2,000), \mathrm{HIF}-1 \beta$ (1:2,000), p-ERK-1/2 (1:1,000), ERK-1/2 (1:2,000), p-JNK-1/2 (1:2,000), JNK-1/2 (1:2,000), p-PKB (1:2,000), PKB (1:2,000), p-S6 (1:2,000), S6 (1:2,000), p-eIF-2 $\alpha$ (1:2,000), eIF-2 $\alpha$ $(1: 2,000)$ or actin $(1: 5,000)$. The membranes were then exposed to secondary antibodies coupled to horseradish peroxidase for $2 \mathrm{~h}$ at room temperature. The membranes were washed three times with TBST at room temperature. Immunoreactivities were detected by ECL reagents. Equal protein loading was assessed by the expression level of actin protein.

Measurement of HIF-1 $\alpha$ protein stability. To determine the effect of NFJ on HIF-1 $\alpha$ protein stability in manganese-treated A549 cells, A549 cells $\left(0.5 \times 10^{6}\right.$ cells in $2 \mathrm{ml} /$ well in a 6 -well plate) were primarily treated without or with manganese for $4 \mathrm{~h}$ to induce high cellular levels of HIF-1 $\alpha$ protein. Cells were then exposed for an additional 1, 3 or 5 min to manganese with or without NFJ in the presence of cycloheximide (CHX), a translation inhibitor, to block ongoing translation. At each time, whole cell lysates were prepared and subjected to immunoblot analysis for HIF-1 $\alpha$ or actin to measure the amounts of HIF-1 $\alpha$ protein remaining in the cells. Actin was used as an internal control to relatively compare the level of HIF-1 $\alpha$ remaining in the cells.

Small interference RNA (siRNA) transfection experiment. A549 cells $\left(0.5 \times 10^{6} / 2 \mathrm{ml} /\right.$ well $/ 6$-well plate) were transfected with 150 pmole of control or eIF-2 $\alpha$ siRNA for $48 \mathrm{~h}$. After 48 post-transfection, cells were treated without or with manganese for an additional $4 \mathrm{~h}$. Whole cell lysates were then prepared and analyzed by Western blotting to measure the 


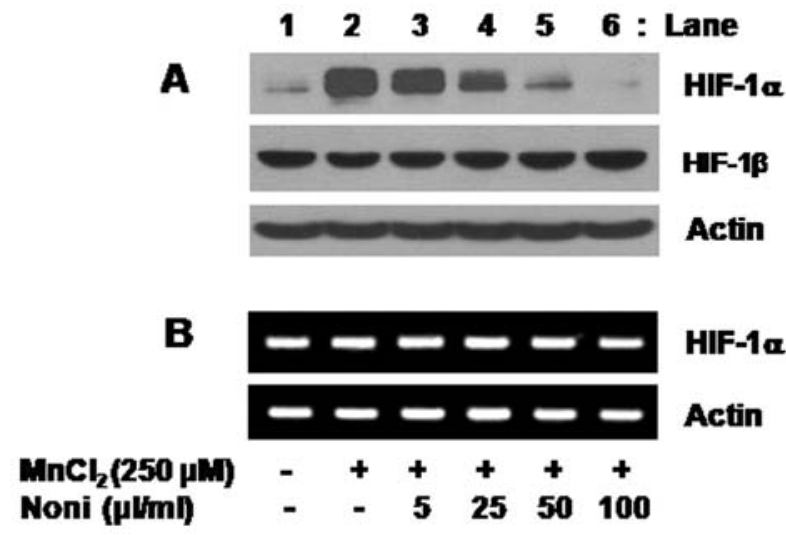

Figure 1.Effect of noni fruit juice (NFJ) on HIF-1 $\alpha$ protein and mRNA expressions in the manganese-treated A549 cells. A549 cells were treated without or with manganese-chloride $\left(\mathrm{MnCl}_{2}\right)(250 \mu \mathrm{M})$ in the absence or presence of $\mathrm{NFJ}$ at the indicated concentrations for $4 \mathrm{~h}$. Whole cell lysates and total-RNA were extracted and subjected to (A) Western blotting and (B) RT-PCR, respectively. Images are representative of three independent experiments.

expression of eIF- $2 \alpha$ or HIF-1 $\alpha$ protein in control or eIF- $2 \alpha$ siRNA-transfected A549 cells.

Statistical analyses. Data are expressed as mean \pm standard error (SE). The significance of the differences was determined by one-way ANOVA. All significance testing was based on a P-value of $<0.05$.

\section{Results}

Noni fruit juice (NFJ) selectively downregulates the expression of HIF-1 $\alpha$ protein in manganese-treated A549 cells. Initially, the effect of manganese on HIF-1 $\alpha$ protein expression in A549 cells was investigated by Western blot analysis. As shown in Fig. 1A, compared with control (lane 1), treatment with manganese ( $250 \mu \mathrm{M}, 4 \mathrm{~h})$ largely induced expression of HIF-1 $\alpha$ protein, but did not influence HIF-1 $\beta$ protein expression in A549 cells (lane 2), suggesting the specificity. Whether NFJ affects the manganese-induced HIF-1 $\alpha$ protein expression in A549 cells was next determined. Interestingly, the exposure of NFJ inhibited the manganese-induced HIF-1 $\alpha$ protein expression in a concentration-dependent manner (lanes 3-6). Particularly, NFJ treatment at $100 \mu \mathrm{l} / \mathrm{ml}$ almost completely suppressed the metal-induced HIF- $1 \alpha$ protein expression (lane 6). Treatment with NFJ at the concentrations applied had no effect on HIF-1 $\beta$ protein expression (lanes 3-6). Control actin protein expression remained constant by treatment with manganese and/or NFJ at the doses applied (Fig. 1A, lanes 1-6). RT-PCR analyses were next carried out to see the effect of manganese and/or NFJ on expression of HIF-1 $\alpha$ mRNA in A549 cells. Of note, as shown in Fig. 1B, there was substantial level of HIF-1 $\alpha$ mRNA in control A549 cells (lane 1). The HIF-1 $\alpha$ mRNA level, however, was not enhanced by treatment with manganese (lane 2) and/or NFJ at the concentrations tested (lanes 3-6). Control actin mRNA expression remained constant under the experimental conditions (Fig. 1B, lanes 1-6). Data of MTS experiments showed that NFJ at $100 \mu \mathrm{l} / \mathrm{ml}$ reduced the viability of A549 cells by
A

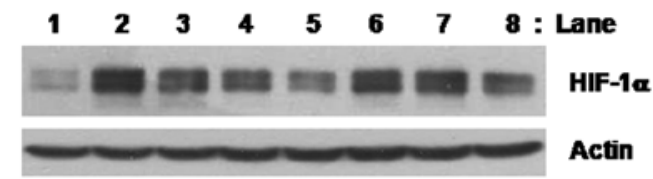

B

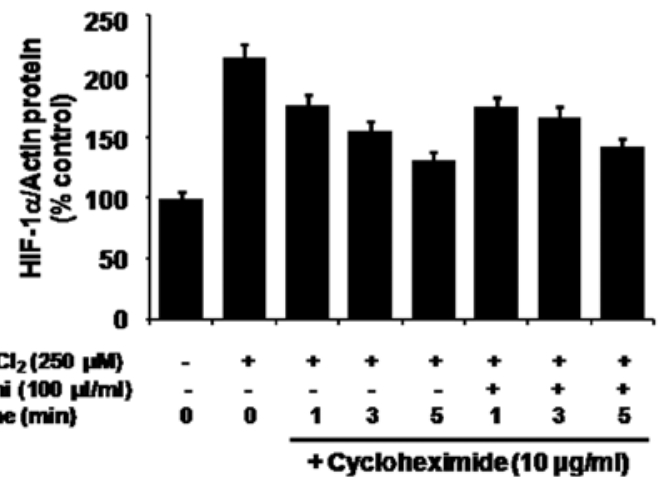

Figure 2. Effect of NFJ on HIF-1 $\alpha$ protein stability in the manganese-treated A549 cells. (A) A549 cells were initially treated without or with $\mathrm{MnCl}_{2}$ $(250 \mu \mathrm{M})$ for $4 \mathrm{~h}$ to highly induce $\mathrm{HIF}-1 \alpha$ protein and then exposed to $\mathrm{MnCl}_{2}$ without or with NFJ $(100 \mu \mathrm{l} / \mathrm{ml})$ in the presence of cycloheximide (CHX), a translational inhibitor for 1, 3 or $5 \mathrm{~min}$. At each time, whole cell lysates were prepared and analyzed by Western blotting to measure the amounts of HIF-1 $\alpha$ protein remaining in the cells at the respective time. Western blots in (A) are representative of three independent experiments. The graph (B) is the semi-quantitative analysis of (A).

$10-15 \%$, suggesting the low cytotoxicity of NFJ at $100 \mu \mathrm{l} / \mathrm{ml}$ (data not shown).

NFJ-mediated downregulation of HIF-1 $\alpha$ protein is not due to alteration of HIF-1 $\alpha$ protein stability. Whether downregulation of manganese-induced HIF-1 $\alpha$ protein by NFJ is due to altered HIF-1 $\alpha$ protein stability (turnover) was next examined by $\mathrm{CHX}$ chase experiments. As shown in Fig. 2A, when translation was blocked by CHX, a translation inhibitor, in the absence of NFJ, there was a rapid time-dependent gradual decrease of HIF-1 $\alpha$ protein level in manganese-treated A549 cells (lanes 3-5), suggesting its intrinsic turnover. However, the intrinsic HIF-1 $\alpha$ protein turnover was not changed by treatment with NFJ (lanes 6-8). Actin protein expression remained constant under the experimental conditions (Fig. 2A, lanes 1-8). Fig. 2B is the semi-quantitative analysis of Fig. 2A.

NFJ largely interferes with phosphorylation of $P K B, E R K-1 / 2$, $J N K-1, S 6$, and eIF-2 $\alpha$ induced by manganese in A549 cells. We next determined the effect of manganese on the phosphorylation of intracellular signaling proteins involved in gene expression and/or translation. As shown in Fig. 3, compared with control (lane 1), manganese treatment at $4 \mathrm{~h}$ increased phosphorylation of ERK-1/2, JNK-1, PKB, S6 and eIF-2 $\alpha$ in A549 cells (lane 2). Importantly, the metal's signal to trigger phosphorylation of ERK-1/2, JNK-1, PKB, S6 and eIF-2 $\alpha$ in A549 cells was strongly affected by NFJ (lanes 3-6). In particular, the strongest inhibitory effect on the metal-induced phosphorylation of these proteins was shown by NFJ at $100 \mu \mathrm{l} /$ $\mathrm{ml}$ (lane 6). However, as shown in Fig. 3A-E, compared with control (lane 1), total expression level of ERK-1/2, JNK-1, PKB, S6 or eIF-2 $\alpha$ was not changed by treatment with manganese (lane 2) and/or NFJ at the doses tested (lanes 3-6). 


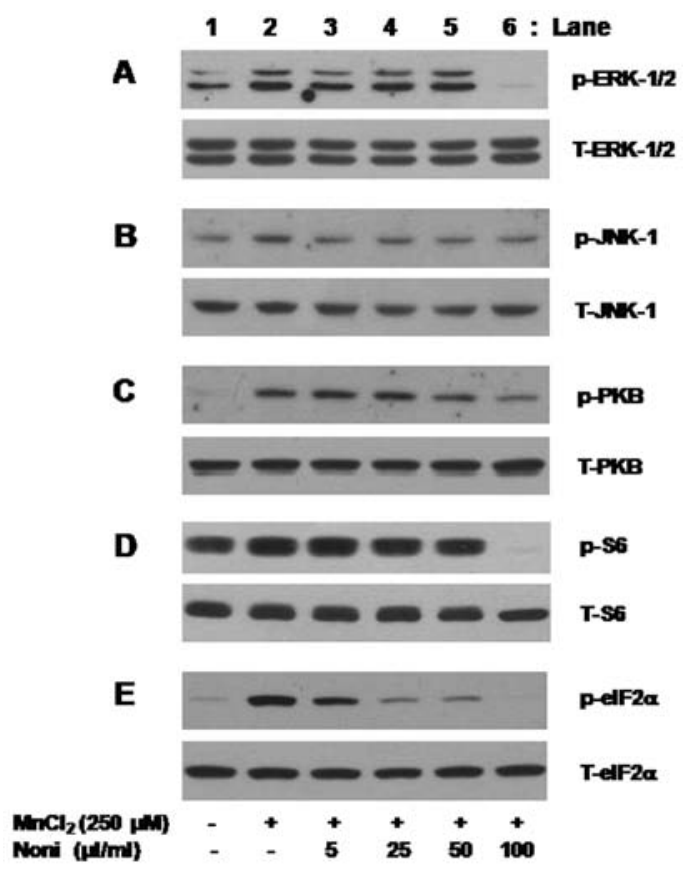

Figure 3. Effect of NFJ on phosphorylation of PKB, ERK-1/2, JNK-1, S6 and eIF- $2 \alpha$ in the manganese-treated A549 cells. A549 cells were treated without or with $\mathrm{MnCl}_{2}(250 \mu \mathrm{M})$ in the absence or presence of NFJ at the indicated concentrations for $4 \mathrm{~h}$. Whole cell lysates were prepared and subjected to Western blotting. The images of the Western blots shown are representative of three independent experiments. p-ERK-1/2, phospho-ERK-1/2; T-ERK1/2, total ERK-1/2; p-JNK-1/2, phospho-JNK-1/2; T-JNK-1/2, total JNK-1/2; p-PKB, phospho-PKB; T-PKB, total PKB; p-S6, phospho-S6; T-S6, total S6; p-eIF- $2 \alpha$, phospho-eIF- $2 \alpha$; T- eIF- $2 \alpha$, total eIF- $2 \alpha$.
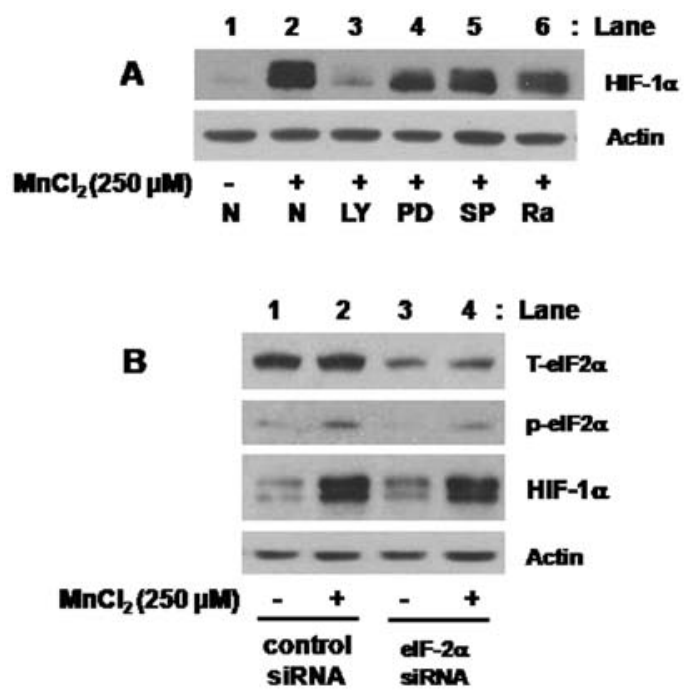

Figure 4. Effect of pharmacological inhibitors or eIF-2 $\alpha$ siRNA transfection on expression of HIF-1 $\alpha$ protein in A549 cells treated with manganese and/or NFJ. (A) A549 cells were treated without or with $\mathrm{MnCl}_{2}(250 \mu \mathrm{M})$ in the absence or presence of NFJ at the indicated concentrations for $4 \mathrm{~h}$. Whole cell lysates were prepared and subjected to Western blotting. (B) A549 cells were treated without or with $\mathrm{MnCl}_{2}(250 \mu \mathrm{M})$ in the absence or presence of LY294002 (LY, $\left.25 \mu \mathrm{M}\right)$, PD98059 (PD, $50 \mu \mathrm{M}$ ) or SP600125 (SP, $25 \mu \mathrm{M}$ ) for $4 \mathrm{~h}$. Whole cell lysates were prepared and subjected to Western blotting. (C) A549 cells were treated without or with $\mathrm{MnCl}_{2}(250 \mu \mathrm{M})$ in the absence or presence of NFJ $(100 \mu 1 / \mathrm{ml})$ or rapamycin (Ra, $200 \mathrm{nM}$ ) for $4 \mathrm{~h}$. Whole cell lysates were prepared and subjected to immunoblot analysis. (D) A549 cells were transfected with 150 pmole of control and eIF- $2 \alpha$ siRNA, respectively, for $48 \mathrm{~h}$. Transfected cells were then treated without or with $\mathrm{MnCl}_{2}(250 \mu \mathrm{M})$ for $4 \mathrm{~h}$. Whole cell lysates were prepared and subjected to Western blotting. The images of the Western blots shown are representative of three independent experiments.

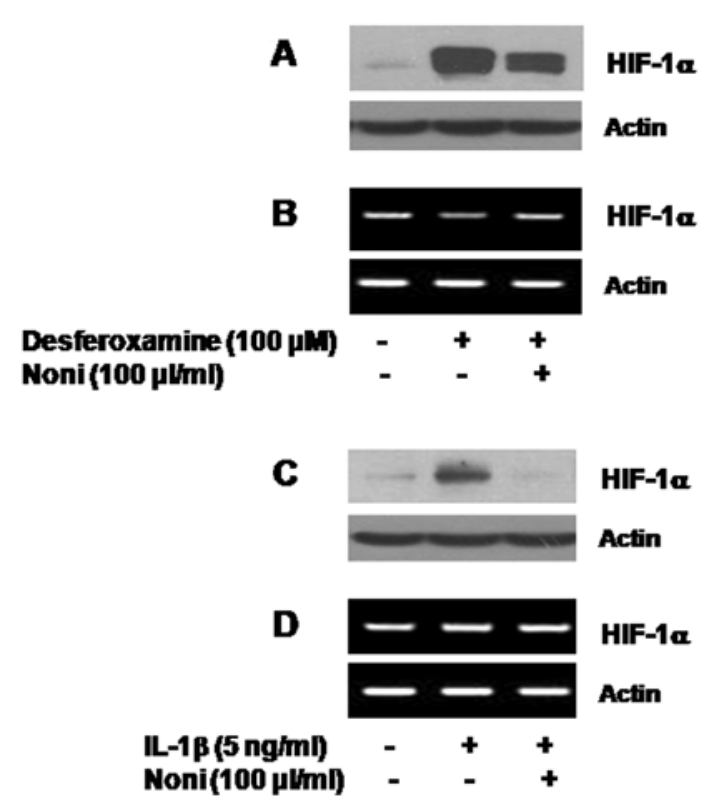

Figure 5. Effect of NFJ on the expression of HIF-1 $\alpha$ by desferoxamine or IL-1 $\beta$ in A549 cells. (A and B) A549 cells were treated without or with desferoxamine $(100 \mu \mathrm{M})$ in the absence or presence of NFJ for $4 \mathrm{~h}$. Whole cell lysates and total-RNA were extracted and subjected to Western blotting and RT-PCR, respectively. (C and D) A549 cells were treated without or with IL-1 $\beta(5 \mathrm{ng} / \mathrm{ml})$ in the absence or presence of NFJ for $4 \mathrm{~h}$. Whole cell lysates and total-RNA were extracted and subjected to Western blotting and RT-PCR, respectively. The images shown are representative of three independent experiments.

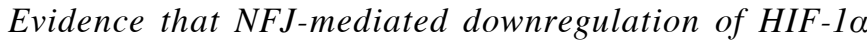
protein is through modulation of activities of PI3K/PKB, ERK-1/2, JNK-1, and S6, but not eIF-2 $\alpha$, in manganese-treated A549 cells. Whether the NFJ's repressive effect on HIF-1 $\alpha$ protein expression is due to blockage of the metal's signal to activate ERK-1/2, JNK-1, PKB and/or S6 was next determined by pharmacological inhibition studies. As shown in Fig. 4A, the manganese-induced HIF-1 $\alpha$ protein expression (lane 2) was greatly repressed by treatment with LY294002 (an inhibitor of PI3K/PKB) (lane 3). There was also a partial inhibition of the manganese-induced HIF-1 $\alpha$ protein expression by treatment with PD98059 (an inhibitor of ERK-1/2) (lane 4), SP600125 (an inhibitor of JNK-1/2) (lane 5), and rapamycin (an inhibitor of the mTOR/p70S6K/S6 pathway) (lane 6), respectively. Actin protein expression remained constant under the experimental conditions (Fig. 4A, lanes 1-6). siRNA transfection targeting eIF- $2 \alpha$ was next carried out to see the role of eIF- $2 \alpha$ in the regulation of HIF-1 $\alpha$ protein expression in manganese and/or NFJ-treated A549 cells. As shown in Fig. 4B, compared with control siRNA-transfected A549 cells (lane 1 and 2), there was a strong reduction of the total expression levels of eIF-2 $\alpha$ (T-eIF-2 $\alpha$ ) in eIF-2 $\alpha$ siRNA-transfected cells (lane 3 and 4). As further shown in Fig. 4B, compared with the phosphorylated levels of eIF- $2 \alpha$ induced by manganese in the control siRNA-transfected cells (lane 2), the phosphorylation levels of eIF- $2 \alpha$ induced by manganese in eIF- $2 \alpha$ siRNA-transfected cells were lower (lane 4). However, there was no difference in the HIF-1 $\alpha$ protein induction by manganese between control siRNA- and eIF-2 $\alpha$ siRNA-transfected A549 cells. 
The ability of $\mathrm{NFJ}$ to repress expression of $\mathrm{HIF}-1 \alpha$ protein by other HIF-1 $\alpha$ inducers in A549 cells. The effect of NFJ on expression of HIF- $1 \alpha$ by other HIF- $1 \alpha$ inducers, such as the iron chelator desferoxamine or the inflammatory cytokine IL-1 $\beta$ in A549 cells was next investigated. As shown in Fig. 5A and B, compared with control (lane 1), treatment with desferoxamine largely induced expression of HIF-1 $\alpha$ protein, but did not affect HIF-1 $\alpha$ mRNA expression in A549 cells (lane 2). Notably, the desferoxamine-mediated induction of HIF-1 $\alpha$ protein expression was in part suppressed by treatment with NFJ at $100 \mu 1 / \mathrm{ml}$ (lane 3). As shown in Fig. 5C and D, compared with control (lane 1), treatment with IL- $1 \beta$ substantially induced expression of HIF- $1 \alpha$ protein, while it slightly increased HIF-1 $\alpha$ mRNA expression in A549 cells (lane 2). Apparently, treatment with NFJ at $100 \mu \mathrm{l} / \mathrm{ml}$ strongly inhibited the IL- $1 \beta$-induced HIF- $1 \alpha$ protein expression, but had no effect on the IL-1 $\beta$-induced HIF- $1 \alpha$ mRNA expression in A549 cells (lane 3). As shown in Fig. 5, actin protein or mRNA expression remained constant by treatment with desferoxamine or IL-1 $\beta$ in the absence or presence of NFJ (lanes 1-3).

\section{Discussion}

Evidence suggests that noni fruit juice (NFJ) has anticancer and antiangiogenic potential. We here report for the first time the ability of NFJ to downregulate the manganese-stimulated expression of HIF-1 $\alpha$ tumor angiogenic transcription factor through modulation of activities of various signaling proteins in A549 human lung cancer cells.

In initial experiments, we have shown that NFJ inhibits the expression of $\mathrm{HIF}-1 \alpha$ protein without changing the HIF-1 $\alpha$ mRNA expression and HIF- $1 \alpha$ protein stability in the manganese-treated A549 cells (Figs. 1 and 2). Expression of HIF-1 $\alpha$ is believed to be regulated at multiple steps, including transcription, translation, and/or post-translation $(8,10,12,19)$. Thus, these findings suggest that the NFJ's repressive effect on the metal-induced HIF-1 $\alpha$ protein expression in A549 cells is not at the level of HIF-1 $\alpha$ transcription and HIF- $1 \alpha$ post-translational stability but at the level of the HIF-1 $\alpha$ translational process and/or accumulation.

Evidence suggests that a variety of intracellular signaling proteins and/or factors mediate the expression of and/or accumulation of HIF-1 $\alpha$ protein in response to extracellular stimuli under normoxic conditions. For example, several experiments have shown a role of ERK-1/2 in the IL-1 $\beta$-induced HIF- $1 \alpha$ protein expression in normal human cytotrophoblast cells (13) and the necessity of activities of PI3K/PKB, ERK-1/2, and JNK-1/2 in the insulin-induced HIF-1 $\alpha$ increase in rat vascular smooth muscle cells (20). Furthermore, there is a study to demonstrate involvement of PKB and p38 MAPK in the diosgenin-induced expression of HIF-1 $\alpha$ in MC3T3-E1 preosteoblast-like cells (21). It also has been recently shown that activities of MAPKs, PKB, PKCs and Src are important for the manganese-induced HIF- $1 \alpha$ protein upregulation in Hep2 human laryngeal cancer cells (17). In agreement with these, the present study has demonstrated that treatment with manganese induces activation of ERK-1/2, JNK-1 and PKB (Fig. 3A-C), and their activations are critical for the metalmediated induction of HIF-1 $\alpha$ protein expression in A549 cells (Fig. 4A). Also, further considering that NFJ strongly inhibits the manganese's signal to activate ERK-1/2, JNK-1 and PKB in A549 cells (Fig. 3A-C), it is likely that the NFJ's downregulatory effect on HIF-1 $\alpha$ protein expression is closely associated with the ability of NFJ to interfere with the metal's signal to activate these signaling components in the cells.

$\mathrm{S} 6$ is a ribosomal protein involved in translation (22). Phosphorylation (activation) of S6 protein is reported to be mediated by the action of an upstream protein kinase p70 S6 kinase (S6K) (23). It has been further demonstrated that $\mathrm{PI} 3 \mathrm{~K} / \mathrm{PKB}$ and mTOR are upstream kinases responsible for phosphorylation of S6K $(24,25)$. The present study has shown that manganese treatment stimulates phosphorylation of S6 in A549 cells but NFJ strongly blocks it (Fig. 3D). Through pharmacological analysis, the present study also reveals that treatment with rapamycin, an $\mathrm{mTOR} / \mathrm{S} 6 \mathrm{~K} / \mathrm{S} 6$ inhibitor partially reduces the metal-induced HIF-1 $\alpha$ protein expression in A549 cells (Fig. 4B). Considering a previous report with $\mathrm{S} 6 \mathrm{~K}$ regulation of angiogenesis via HIF-1 $\alpha$ expression in ovarian cancer cells (26), it is speculative that interference with the mTOR/S6K/S6 pathway may in part contribute to the NFJ-mediated reduction of HIF-1 $\alpha$ protein expression in this system. Evidence suggests that eIF- $2 \alpha$ is a translational regulator and the phosphorylation (on Serine ${ }^{51}$ ) of eIF- $2 \alpha$ by stress kinases, such as protein kinase $\mathrm{R}$, leads to its inactivation and inhibition of global translation (27). Notably, the present study has demonstrated that manganese treatment also leads to increased phosphorylation of eIF- $2 \alpha$ in A549 cells while NFJ strongly blocks it (Fig. 3E). However, analysis of siRNA transfection performed in the present study has unveiled that knockdown of eIF- $2 \alpha$ expression and activity does not influence the manganese-induced expression of HIF-1 $\alpha$ protein in A549 cells as well as the NFJ's repressive effect on the metalinduced HIF-1 $\alpha$ protein upregulation in A549 cells (Fig. 4B), suggesting no link between the eIF-2 $\alpha$ pathway and HIF-1 $\alpha$ protein upregulation or downregulation in response to manganese and/or NFJ exposure.

NFJ contains a variety of compounds, including iridoids, flavonol glycosides, lignans, ursolic acid, $\beta$-sistosterol, and scopoletin $(1,2)$. Interestingly, it has been recently shown that ursolic acid enriched in NFJ and also in many other plant products suppresses endogenous mRNA expression of multiple pro-angiogenic genes, including HIF- $1 \alpha$, in human liver cancer cells (28), thereby suggesting its antiangiogenic potential. Though not assessed herein, it is suggested that among the constituents of noni juice, ursolic acid may be a key compound associated with the NFJ's repressive effect on the manganese-induced HIF-1 $\alpha$ protein expression in A549 cells. To answer this question, we are currently investigating if ursolic acid influences expression of HIF-1 $\alpha$ protein induced by manganese in A549 cells.

The present study also provides experimental evidence that the NFJ's repressive effect on HIF-1 $\alpha$ protein expression is not limited to the manganese signal. This is based on the facts that NFJ is further able to strongly inhibit the desferoxamine- or IL-1 $\beta$-induced HIF-1 $\alpha$ protein expression without affecting HIF-1 $\alpha$ mRNA expression in A549 cells (Fig. 5).

High exposure of manganese is believed to be a risk factor for respiratory diseases (29). Evidence also indicates the manganese-mediated pulmonary toxicities characteristic of 
inflammatory and angiogenic changes $(30,31)$. Overexpression of HIF- $1 \alpha$ has been implicated in multiple pulmonary pathologies, including inflammation, hypertension, and cancer $(18,32,33)$. In view of this, the present findings with the strong inhibitory effect of NFJ or LY294002 on the manganeseinduced HIF- $1 \alpha$ protein expression in A549 cells may have significance to emphasize that single and/or combined treatment with NFJ or LY294002 may be useful for diminishing the manganese-mediated lung pathologies in which overexpression of HIF- $1 \alpha$ is problematic.

In conclusion, the present study demonstrates for the first time that NFJ reduces expression of HIF- $1 \alpha$ at the protein level in the manganese-treated A549 human lung carcinoma cells. The NFJ-mediated repression of HIF-1 $\alpha$ protein appears to be largely associated with the ability of NFJ to interfere with the manganese's signal to activate PKB, ERK-1/2, JNK-1 and S6.

\section{Acknowledgements}

The author would like to express his profound appreciation to Professor Jae-Bum Kim for proofreading this manuscript.

\section{References}

1. Potterat $\mathrm{O}$ and Hamburger M: Morinda citrifolia (noni) fruitphytochemistry, pharmacology, safety. Planta Med 73: 191-199, 2007.

2. Samoylenko V, Zhao J, Dunbar DC, Khan IA, Rushing JW and Muhammad I: New constituents from noni (Morinda citrifolia) fruit juice. J Agric Food Chem 54: 6398-6402, 2006.

3. Akihisa T, Matsumoto K, Tokuda H, Yasukawa K, Seino K, Nakamoto K, Kuninaga H, Suzuki T and Kimura Y: Antiinflammatory and potential cancer chemopreventive constituents of the fruits of Morinda citrifolia (noni). J Nat Prod 70: 754-757, 2007.

4. Wang MY and Su C: Cancer preventive effect of Morinda citrifolia (noni). Ann NY Acad Sci 952: 161-168, 2001.

5. Hornick CA, Myers A, Sadowska-Krowicka H, Anthony CT and Woltering EA: Inhibition of angiogenic initiation and disruption of newly established human vascular networks by juice from Morinda citrifolia (noni). Angiogenesis 6: 143-149, 2003.

6. Wang GL, Jiang BH, Rue EA and Semenza GL: Hypoxiainducible factor 1 is a basic-helix-loop-helix-PAS heterodimer regulated by cellular $\mathrm{O}_{2}$ tension. Proc Natl Acad Sci USA 92: 5510-5514, 1995.

7. Huang LE, Gu J, Schau M and Bunn HF: Regulation of hypoxia-inducible factorlalpha is mediated by an $\mathrm{O}_{2}$-dependent degradation domain via the ubiquitin proteasome pathway. Proc Natl Acad Sci USA 95: 7987-7992, 1998.

8. Tanimoto K, Makino Y, Pereira T and Poellinger L: Mechanism of regulation of the hypoxia-inducible factor-1 alpha by the von Hippel-Lindau tumor suppressor protein. EMBO J 19: 4298-4309, 2000.

9. Ivan M, Kondo K, Yang H, Kim W, Valiando J, Ohh M, Salic A, Asara JM, Lane WS and Kaelin Jr WG: HIFalpha targeted for VHL-mediated destruction by proline hydroxylation: implications for $\mathrm{O}_{2}$ sensing. Science 292: 464-468, 2001.

10. Salceda S and Caro J: Hypoxia-inducible factor 1alpha(HIF-1alpha) protein is rapidly degraded by the ubiquitin-proteasome system under normoxic conditions. Its stabilization by hypoxia depends on redox-induced changes. J Biol Chem 272: 2642-22647, 1997.

11. Semenza GL: Hypoxia-inducible factor 1: master regulator of $\mathrm{O}_{2}$ homeostasis. Curr Opin Genet Dev 8: 588-594, 1998.

12. Jung YJ, Isaacs JS, Lee S, Trepel J and Neckers L: IL-1betamediated up regulation of HIF-1alpha via an NFkappaB/COX-2 pathway identifies HIF-1 as a critical link between inflammation and oncogenesis. FASEB J 17: 2115-2117, 2003.

13. Qian D, Lin HY, Wang HM, Zhang X, Liu DL, Li QL and Zhu C: Normoxic induction of the hypoxic-inducible factor-1 alpha by interleukin-1 beta involves the extracellular signal-regulated kinase $1 / 2$ pathway in normal human cytotrophoblast cells. Biol Reprod 70: 1822-1827, 2004
14. Fukuda R, Hirota K, Fan F, Jung YD, Ellis LM and Semenza GL: Insulin like growth factor 1 induces hypoxia-inducible factor 1-mediated vascular endothelial growth factor expression, which is dependent on MAP kinase and phosphatidylinositol 3-kinase signaling in colon cancer cells. J Biol Chem 277: 38205-38211, 2002.

15. Tessier DM and Pascal LE: Activation of MAP kinases by hexavalent chromium, manganese and nickel in human lung epithelial cells. Toxicol Lett 167: 114-121, 2006.

16. Han J, Lee JS, Choi D, Lee Y, Hong S, Choi J, Han S, Ko Y, Kim JA, Kim YM and Jung Y: Manganese (II) induces chemical hypoxia by inhibiting HIF-prolyl hydroxylase: implication in manganese-induced pulmonary inflammation. Toxicol Appl Pharmacol 235: 261-267, 2009.

17. Shin HJ, Choi MS, Ryoo NH, Nam KY, Park GY, Bae JH, Suh SI, Baek WK, Park JW and Jang BC: Manganese-mediated upregulation of HIF-1alpha protein in Hep2 human laryngeal epithelial cells via activation of the family of MAPKs. Toxicol In Vitro 24: 1208-1214, 2010

18. Crittenden PL and Filipov NM: Manganese-induced potentiation of in vitro proinflammatory cytokine production by activated microglial cells is associated with persistent activation of $\mathrm{p} 38$ MAPK. Toxicol In Vitro 22: 18-27, 2008.

19. Semenza GL: Expression of hypoxia-inducible factor 1: mechanisms and consequences. Biochem Pharmacol 59: 47-53, 2000.

20. Doronzo G, Russo I, Mattiello L, Riganti C, Anfossi G and Trovati M: Insulin activates hypoxia-inducible factor-1alpha in human and rat vascular smooth muscle cells via phosphatidylinositol-3 kinase and mitogen-activated protein kinase pathways: impairment in insulin resistance owing to defects in insulin signaling. Diabetologia 49: 1049-1063, 2006.

21. Yen ML, Su JL, Chien CL, Tseng KW, Yang CY, Chen WF, Chang CC and Kuo ML: Diosgenin induces hypoxiainducible factor-1 activation and angiogenesis through estrogen receptor-related phosphatidylinositol 3-kinase/Akt and p38 mitogen-activated protein kinase pathways in osteoblasts. Mol Pharmacol 68: 1061-1073, 2005.

22. Meyuhas O: Physiological roles of ribosomal protein S6: one of its kind. Int Rev Cell Mol Biol 268: 1-37, 2008.

23. Berven LA and Crouch MF: Cellular function of p70S6K: a role in regulating cell motility. Immunol Cell Biol 78: 447-451, 2000.

24. Dickson LM, Lingohr MK, McCuaig J, Hugl SR, Snow L, Kahn BB, Myers Jr MG and Rhodes CJ: Differential activation of protein kinase $\mathrm{B}$ and $\mathrm{p} 70(\mathrm{~S} 6) \mathrm{K}$ by glucose and insulin-like growth factor 1 in pancreatic beta-cells (INS-1). J Biol Chem 276: 21110-21120, 2001.

25. Fang CX, Yang X, Sreejayan N and Ren J: Acetaldehyde promotes rapamycin-dependent activation of p70(S6K) and glucose uptake despite inhibition of Akt and mTOR in dopaminergic SH-SY5Y human neuroblastoma cells. Exp Neurol 203: 196-204, 2007.

26. Bian CX, Shi Z, Meng Q, Jiang Y, Liu LZ and Jiang BH: P70S6K1 regulation of angiogenesis through VEGF and HIF-1alpha expression. Biochem Biophys Res Commun 398: 395-399, 2010.

27. De Haro C, Méndez R and Santoyo J: The eIF-2alpha kinases and the control of protein synthesis. FASEB J 10:1378-1387, 1996.

28. Lin CC, Huang CY, Mong MC, Chan CY and Yin MC: Antiangiogenic potential of three triterpenic acids in human liver cancer cells. J Agric Food Chem 59: 755-762, 2011.

29. Dorman DC, Struve MF, Gross EA, Wong BA and Howroyd PC: Sub chronic inhalation of high concentrations of manganese sulfate induces lower airway pathology in rhesus monkeys. Respir Res 21: 121, 2005.

30. Bredow S, Falgout MM, March TH, Yingling CM, Malkoski SP, Aden J, Bedrick EJ, Lewis JL and Divine KK: Subchronic inhalation of soluble manganese induces expression of hypoxiaassociated angiogenic genes in adult mouse lungs. Toxicol Appl Pharmacol 221: 148-157, 2007.

31. Gray RD, Duncan A, Noble D, Imrie M, O'Reilly DS, Innes JA, Porteous DJ, Greening AP and Boyd AC: Sputum trace metals are biomarkers of inflammatory and suppurative lung disease. Chest 137: 635-641, 2010.

32. Semenza GL: Involvement of hypoxia-inducible factor 1 in pulmonary pathophysiology. Chest 128 (Suppl 6): S592-S594, 2005.

33. Tuder RM, Yun JH, Bhunia A and Fijalkowska I: Hypoxia and chronic lung disease. J Mol Med 85: 1317-1324, 2007. 